the interest of the child, notify the school authorities as soon as the condition is discovered." Are parents and children entitled to no privacy in an increasingly bureaucratic welfare state?

Dr. S. D. V. Weller (11 January, 1969, p. 117) gave a frightening example of how information of a purely tentative kind, recorded in school medical records, could be seriously damaging to career finding many years afterwards. While community measures are necessary to help many of those who suffer from chronic epilepsy, it is equally important that those who are going to recover or to improve to such a degree as to be able to perform work and maintain themselves adequately should be protected so far as possible from publicity, which could have an adverse effect on their ability to secure positions which are within their competence.-I am, etc.,

\section{T. Maclay.}

Uffculme Clinic,

\section{REFERENCE}

1 Bainbridge, J. M., Health Trends, 1970, 2, No. 1, p. 15.

\section{Mass Radiography}

SIR,-In reply to Dr. J. Rimington and J. I. Capper (28 March, p. 821), we would like to point out that one of the main objects of the Adrian report ${ }^{1}$ was to cut down unnecessary radiation to the patient. Surely they would agree that to give a patient 15 times more than the dose for a large film comes into the category of unnecessary radiation?

With reference to their remarks about the cost to the taxpayer, they quote only one category of referral by local authorities. At least half of the work load of one static unit we know of comprises the following categories: (1) pre-employment; (2) examinations for private firms for superannuation purposes; (3) emigration; (4) routine pre-employment for local authorities; and (5) examinations for the police and Shipping Federation, etc.

As, under the terms and conditions of service, these fall into Category II, then the private firms or local authorities requesting them, or in the case of emigrants the person himself, should pay the appropriate fee. Surely one cannot consider that all the above referrals are the responsibility of the taxpayer?

Finally, let us make it quite clear that we believe everyone who is entitled to the chest $x$-ray should have one with the minimum dose, even if this is going to cost the N.H.S. a little more for full-size films.We are, etc.,

\section{R. Wallace Jones.}

M. GOLDMAN.

X-ray Department,

$$
\text { Fazakerley Hospital, }
$$
Liverpool.

\section{REFERENCE} 1 Radiological Hazards to Patients, Interim Report of London, H.M.S.O., 1959.

\section{Hearing Aids in Glue Ear}

SIR,-I have read Mr. S. Mawson's reply (7 March, p. 632) to my letter (14 February, p. 432) concerning your leading article on glue ear (6 December, 1969, p. 578).

I would like to stress that the British Medical fournal has a world-wide distribution and a very significant reputation as $\mathrm{far}$ as the quality of its articles is concerned. I would further stress that its leading articles on any special subject might well be thought to reflect the best British medical opinion in that particular specialty. I find it hard to believe that this would recommend a hearing aid in any case of glue ear. The fact that I am Britishtrained would tend to reinforce my opinion in this regard. I would, however, like to invite further opinions from other British specialists in otology with regard to this particular aspect of the management of glue ear.

I have been inserting Teflon tubes into these ears for many years and would consider that I have treated many hundreds of cases. I have never seen a permanent perforation, a middle ear cholesteatoma, or any other complication to the tympanic membrane or tympanum from the insertion of these tubes. I would be most interested to learn of the opinions of other otologists in the United Kingdom and around the world with regard to this matter.

I do not believe that untreated glue ear tends to disappear at puberty. I am convinced, however, that if the glue is not removed and the middle ear kept aerated, there is a grave risk of chronic adhesive and atelectatic otitis being present at this age. What guarantee does Mr. Mawson have that these patients will return for frequent inspections as instructed?

May I again ask why should one prescribe a hearing aid, apart from the above considerations, for a form of deafness which is immediately relieved by a simple surgical procedure, even if this is liable to some minor complications in what must be an extremely small percentage of cases.-I am, etc.,

Edmonton, Alberta,

John KeOHANE. Canada.

\section{Peripatetic Patient}

SIR,-In the correspondence column (4 October 1969, p. 52) you published a letter about a man called Michael Lannon, who at that time had been known to attend Mount Vernon Hospital and the Mildmay Mission Hospital complaining of chest pain. I have met him before at Luton and Dunstable Hospital with the same story of being a blind physiotherapist. At that time he claimed to have had a coronary in New Zealand some time previously, and had needle marks in the right antecubital fossa. He now calls himself Michael Conlan.

Recently he was admitted to St. Albans City Hospital when he was recognized, and I feel it is worth drawing to your attention that on this particular admission he said that he was a computer programmer, and that he had recently had a coronary thrombosis in Palma, Majorca. Since your previous report his E.C.G. has remained unchanged-namely, inverted and flat $T$ waves in V3-6. However, he has acquired a thrombosis of the left antecubital vein.-I am, etc.,

\section{St. Albans City Hospital,}

R. B. ROYDS.

\section{House-surgeon's Day}

SIR,-I have read some tripe in my time, but nothing quite so bad as the letter written by Mr. John Whittingdale (25 April, p. 240) on "House-surgeon's Day." Just exactly what sort of a man describes the wife of a young doctor (exams or no) as a "burden" and his "premature marriage" (at 24-plus?) a "distracting handicap"?-I am, etc.,

\section{Cheadle,}

I. J. KERBY.

SIR,-Mr. John Whittingdale (25 April, p. 240) thinks it is a distastrous handicap for an ambitious hospital doctor to marry prematurely. By "prematurely" he presumably means before he is a consultant and therefore in his late 30s.

Most doctors, who have normal reactions to members of the opposite sex, do not wish to wait until they are approaching middle age before getting married.

It is not to the credit of the hospital career structure in this country that some doctors feel obliged to deny themselves "the burden of a wife."-I am, etc.,

STEPHEN J. COHEN.

Obstetric Department,

Edgware General Hospital,

\section{Blood-gas Tension and Aerosols}

SIR,-There have been a number of letters recently (29 November, p. 557 and 17 January, p. 173) on the subject of the effect of inhaled bronchodilators on arterial oxygen tension $\left(\mathrm{PO}_{2}\right)$. To these preliminary results must now be added an advertisement by Riker Laboratories claiming advantages for one of their inhaled bronchodilators. May I suggest a pause for more thought and study as the explanation and importance of recent observations on this subject are not known.

The fall in arterial $\mathrm{Po}_{2}$ that has been observed should be seen in perspective. The fall is usually small, and in the reported studies would have a minor consequence in terms of oxygen supply to tissues. This also has to be seen in conjunction with the cogent arguments suggesting that a low $\mathrm{PO}_{2}$ is not necessarily as dangerous a state as often taught. ${ }^{1}$ Not only are the reports not entirely unanimous, but further information is required about the change in arterial blood gases in response to various doses of inhaled bronchodilators and in patients with more severe airways obstruction where a fall in $\mathrm{Po}_{2}$ may become critical.

In addition to more information about the change in blood gases, some thought is also required about its cause. There are a number of explanations, and a profitable line of inquiry would probably be to study the effect of bronchodilators on pulmonary haemodynamics. It is in this context that I am concerned about the advertised claims of Medihaler-duo. The inclusion of phenylephrine may, in the dose recommended, protect the pulmonary circulation from effects of isoprenaline, but it must be remembered that phenylephrine stimulates $\alpha$-receptors. This stimulation can cause pulmonary hypertension, and thus inhalers containing phenylephrine may accentuate pulmonary hypertension if taken in excess by patients with severe airways obstruction. 